Citation: N. Castel-Branco (2021) Dissecting with Numbers: Mathematics in Nicolaus Steno's Early Anatomical Writings, 1661-64. Substantia 5(1) Suppl.: 29-42. doi: 10.36253/Substantia-1276

Copyright:@2021 N. Castel-Branco. This is an open access, peer-reviewed article published by Firenze University Press (http://www.fupress.com/substantia) and distributed under the terms of the Creative Commons Attribution License, which permits unrestricted use, distribution, and reproduction in any medium, provided the original author and source are credited.

Data Availability Statement: All relevant data are within the paper and its Supporting Information files.

Competing Interests: The Author(s) declare(s) no conflict of interest.

\section{Dissecting with Numbers: Mathematics in Nicolaus Steno's Early Anatomical Writings, 1661-64}

\author{
Nuno CASTel-Branco ${ }^{1}$ \\ Department of History of Science and Technology, Johns Hopkins University, $3400 \mathrm{~N}$. \\ Charles Street, Gilman Hall 301, Baltimore, MD 21218
}

\begin{abstract}
At the height of his scientific career, the anatomist Nicolaus Steno published the Elementorum myologice specimen (Florence, 1667), a book unlike any other anatomy book until then. Rather than an anatomy book, it seemed more like a book of mathematics, with propositions, lemmas and corollaries. Steno is thought to have developed his mathematical interests in Florence with the school of Galileo. However, this article challenges this interpretation and argues that Steno's turn towards mathematics was a gradual process that began earlier in Copenhagen and Leiden. By surveying Steno's early anatomical writings, mathematical methods such as quantification measurements, mechanical analogies, and geometrical models come to light. More importantly, these methods are read in their own context, by considering what mathematics really meant in the early modern period and how anatomists used it. As such, this article provides a more complete picture of Steno's interest in mathematics and it sheds new light on the rise of mathematics in the early modern life sciences.
\end{abstract}

Keywords: Nicolaus Steno, Early Modern Science, History of Anatomy, Mathematization, Mechanical Philosophy, Mixed Mathematics, Quantification, Dissection Culture.

\title{
INTRODUCTION
}

When the anatomist Nicolaus Steno arrived in Florence and published the Elementorum myologiae specimen (1667), he claimed that the study of the muscles had to become "part of mathematics" and that the cause of "many errors ... in the description of the human body" was that "until now anatomy has disdained the laws of mathematics." 2 The book seemed more like a

\footnotetext{
${ }^{1}$ I would like to thank the editors Stefano Dominici and Gary Rosenberg, as well as the reviewers Peter Dear, Jeremy Gray and François Duchesneau for very helpful comments and suggestions. I also benefitted much from discussions with Troels Kardel and John Heng at the workshop "Galilean Foundations for a Solid Earth" in October 2019, in Florence. Finally, a special thanks to Evan Ragland and María Portuondo who kindly read and commented on an earlier version of this article.

${ }^{2}$ Nicolaus Steno, Elementorum myologiae specimen (Florence, 1667), p. iii-iv: "non posse in musculo distincte partes eius nominari, nec motum eiusdem considerari feliciter, nisi Matheseos pars
} 


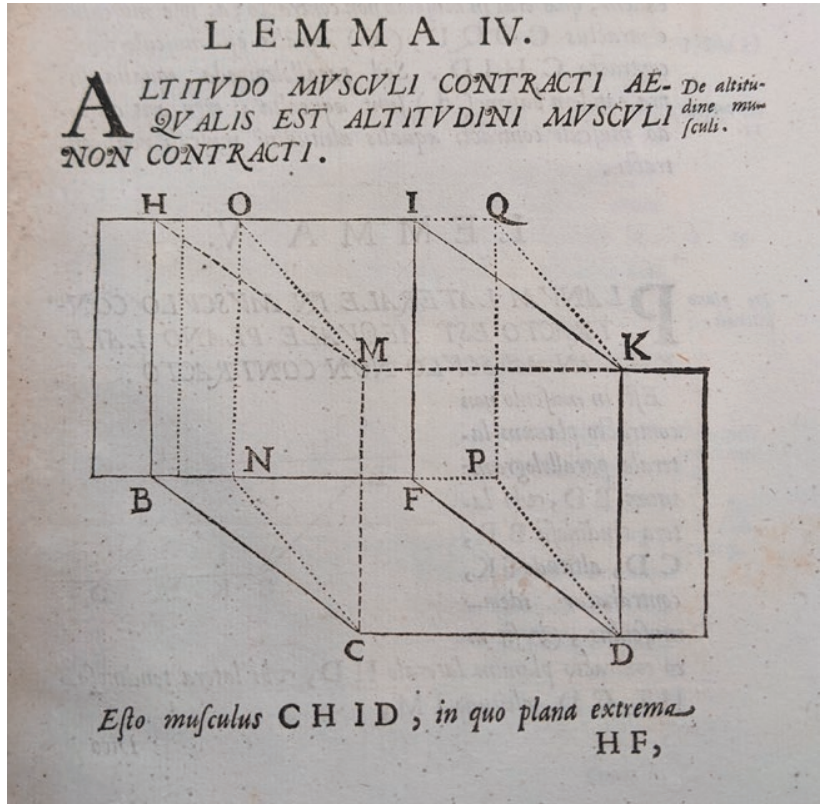

Figure 1. "Lemma IV: The height of a contracted muscle is equal to the height of the non-contracted muscle." Steno, Elementorum myologice specimen, p. 21; BOP, p. 667.

mathematics than an anatomy book, due to its propositions, lemmas and corollaries, and strong epistemological claims about the role of mathematics in the study of nature (fig. 1). ${ }^{3}$ This mathematical approach was seen likewise in Steno's most famous work, also published in Florence, the De solido intra solidum naturaliter contento (1669), where he laid down the principles of superposition of the Earth's strata and in which he described the formation of crystals and of the Tuscan mountains by means of geometry. ${ }^{4}$ Since Steno's earlier works did not

Myologia fieret," and "innumerabilium errorum, quibus humani corporis historia foedè inquinatur, quàm quod Matheseos leges Anatome hactenus indignata fuerit." For a full English translation see Troels Kardel and Paul Maquet, Nicolaus Steno: Biography and Original Papers of a $17^{\text {th }}$ Century Scientist, $2^{\text {nd }}$ ed. (Berlin: Springer, 2018) (hereafter BOP), p. 651. All translations are from BOP unless the Latin is provided in the footnote, in which case they are mine.

${ }^{3}$ For in-depth studies of the Elementorum myologice specimen see Troels Kardel, Steno on Muscles: Introduction, Texts, Translations, (Philadelphia: The American Philosophical Society, 1994); Raphaële Andrault, "Mathématiser l'anatomie: la myologie de Stensen (1667)," Early Science and Medicine, 15 (2010), pp. 505-536; Domenico Bertoloni Meli, "The Collaboration between Anatomists and Mathematicians in the mid-Seventeenth Century with a Study of Images as Experiments and Galileo's Role in Steno's Myology,' Early Science and Medicine, 13:6 (2008), pp. 665-709.

${ }^{4}$ Nicolaus Steno, De solido intra solidum naturaliter contento dissertationis prodromus (Florence, 1669), 78-80; BOP, pp. 822-825. See also Alan Cutler, The Seashell on the Mountaintop: A Story of Science, Sainthood, and the Humble Genius Who Discovered a New History of the Earth (New York: Dutton, 2003), pp. 105-118. display such an explicit use of mathematics, it may seem that he completely changed his research methods when he arrived in Florence. However, as this article argues, that was not the case.

Rather than a sudden shift, Steno's turn towards mathematics was a gradual process. Early in his anatomical career, Steno used methods directly associated with the early modern pure and mixed mathematics. The mixed mathematic disciplines, such as astronomy, mechanics or optics, used the methods of pure mathematics - arithmetic and geometry - to explain natural phenomena. Such methods included quantification measurements, geometrical models, and even the axiomatic structure of mathematical treatises. ${ }^{5}$ Simple uses of quantification like counting did not necessarily entail an interest in mathematical methods, unless they were used to make stronger epistemological claims. Scholars who worked on mixed mathematics aimed to achieve higher levels of certainty in their description of the natural world. ${ }^{6}$ For that reason, seventeenth-century mixed mathematics, later known as physico-mathematics, used not only mathematical methods but also new experimentation techniques and mechanical analogies to explain natural phenomena. ${ }^{7}$ For example, historian Peter Dear explains that the book Ars magnesia (Würzburg, 1631) by the Jesuit Athanasius Kircher (16021680) was "a physico-mathematical disquisition" on magnetism where experimental accounts were presented in the form of theorems. ${ }^{8}$ Steno carefully studied the second edition of this book as a university student in Copenhagen, including the chapters where Kircher illustrated magnetic attraction by means of hydrostatic devices. ${ }^{9}$

Besides outlining Steno's early uses of mathematics and mechanical analogies, this article shows that such uses derived in large part from his interest in mixed mathematics and not so much from the mechanical philosophies of his time. ${ }^{10}$ Although Steno may be

${ }^{5}$ Kirsti Andersen and Henk Bos, "Pure Mathematics," in Katharine Park and Lorraine Daston (eds.), Cambridge History of Science, vol. 3: Early Modern Science, pp. 696-723, esp. 702.

${ }^{6}$ Peter Dear, Discipline and Experience: The Mathematical Way in the Scientific Revolution (Chicago: Chicago Press, 1995), pp. 32-44; Rivka Feldhay, "The use and abuse of mathematical entities: Galileo and the Jesuits revisited," in Peter Machamer (ed.), The Cambridge Companion to Galileo (Cambridge: Cambridge Univ. Press, 1998), pp. 80-145, esp. 83-100.

${ }^{7}$ Dear, Discipline and Experience, pp. 32-62, 151-79.

${ }^{8}$ Peter Dear, "Mixed Mathematics", in P. Harrison, R. Numbers and M. Shank (eds.), Wrestling with Nature: From Omens to Science (Chicago: Chicago Press, 2011), p. 156; Dear, Discipline and Experience, 172-9.

${ }_{9}^{9}$ August Ziggelaar (ed.), Chaos: Niels Stensen's Chaos-manuscript with Introduction, Notes and Commentary (Copenhagen: Danish Library of Science and Medicine, 1997), p. 122; Athanasius Kircher, Magnes sive de arte magnetica (Cologne, 1643), pp. 527-9.

${ }^{10}$ This was also the case for the anatomist Fabricius d'Acquapendente (1533-1619), see Peter Distelzweig, "Fabricius's Galeno-Aristotelian 
described as a mechanical philosopher, this does not mean that he followed strictly the mechanical philosophies of René Descartes (1596-1650) and Pierre Gassendi (1592-1655). ${ }^{11}$ Many non-mechanical, early-modern scholars also used quantification methods and mechanical analogies in medicine and anatomy, as seen in the case of the vitalist Johannes Baptista Van Helmont (15801644) and the Aristotelian William Harvey (1578-1657). ${ }^{12}$

Steno's early interests in mathematics have two important historical implications. First, they provide a more complete picture of Steno's personal interest in mathematics. Steno never wrote about what made him turn towards a geometrical explanation of the muscles or when he decided to do it. But historians tend to associate this mathematical turn with the mathematical school of Galileo, whose followers Steno met in Italy in 1666. ${ }^{13}$ Giovanni Alfonso Borelli (1608-1679), a mathematician trained in the school of Galileo, also published, more than ten years after Steno, the De motu animalium (Rome, 1680-1), a two-volume book on the motion of animals similar to Steno's Elementorum myologice specimen in many ways. ${ }^{14} \mathrm{~A}$ few months after arriving in Florence, Steno asked Borelli to "teach him some things of geometry," as Borelli reported in a letter to Marcello Malpighi (1628-1694). ${ }^{15}$ Moreover, it was in collaboration with the mathematician Vincenzo Viviani (1622-1703),

Teleomechanics of Muscle," in Justin Smith (ed.), The Life Sciences in Early Modern Philosophy (Oxford: Oxford Univ. Press, 2014); see also Alan Gabbey, "What Was 'Mechanical' about 'The Mechanical Philosophy'?" in C. Palmerino and J. Thijssen (eds.), The Reception of the Galilean Science of Motion in Seventeenth-Century Europe (Dordrecht: Springer, 2004), pp. 11-24, esp. 21-23.

${ }^{11}$ For a recent account of the complexity of early modern mechanical philosophies see D. Bertoloni Meli, Mechanism: A Visual, Lexical and Conceptual History (Pittsburgh: University of Pittsburgh Press, 2019), pp. 3-24.

${ }^{12}$ For quantification in Van Helmont, see William Newman and Lawrence Principe, Alchemy Tried in the Fire: Starkey, Boyle, and the Fate of Helmontian Chymistry (Chicago, Univ. of Chicago Press, 2002), pp. 56-91; for Harvey as a non-mechanical philosopher despite his use of mechanical analogies see P. Distelzweig, "Mechanics' and Mechanism in William Harvey's Anatomy: Varieties and Limits," in P. Distelzweig, B. Goldberg and E. Ragland, Early Modern Medicine and Natural Philosophy (Dordrecht: Springer, 2016), pp. 117-40.

${ }^{13}$ See Gustav Scherz's biography in BOP, pp. 185-193; Roberto Angeli, Niels Stensen (Turin: Edizioni San Paolo, 1996; $1^{\text {st }}$ ed., 1968), pp. 120-127.

${ }^{14} \mathrm{See}$, for example, Richard Westfall, The Construction of Modern Science: Mechanisms and Mechanics (Cambridge: Cambridge Univ. Press, 1977), pp. 94-96; and Thomas Settle, "Borelli, Giovanni Alfonso," in Complete Dictionary of Scientific Biography, vol. 2. (Detroit, MI: Charles Scribner's Sons, 2008), pp. 306-314. For Borelli's mathematical training see Bertoloni Meli, "The Collaboration between Anatomists and Mathematicians," p. 678. Most of Borelli's books up to then were all on mathematics.

${ }^{15}$ Borelli to Malpighi, 17 July 1666, in Howard Adelmann, The Correspondence of Marcello Malpighi, 5 vols. (London: Cornell University Press, 1975), vol. 1, p. 318: "lo Stenone è qui, ... e mi ha detto ... che vuol che io gl'insegni qualche cosa di geometria."
Galileo's last disciple, that Steno published the Elementorum myologice specimen, as historian Domenico Bertoloni Meli explains. ${ }^{16}$ Thus, it would seem reasonable to assume that Steno travelled to Tuscany to learn mathematics in the Italian school of "the great Galileo," as Steno later referred to him. ${ }^{17}$

However, a letter recently acquired by the Royal Danish Library suggests that Steno's interests in mathematics were more developed than previously thought before his arrival in Italy. In the same year of Steno's arrival, Prince Leopoldo de' Medici (1617-75) mentioned to a friend the arrival of "Mr. Steno, a Danish anatomist of young age but remarkable in his work... and a great geometer." 18 This means that Steno displayed his mathematical skills to the Medici Prince before having any prolonged contact with Borelli and Viviani. While this does not diminish the influence of a Galilean school after Steno's arrival in Italy, it implies that Steno's mathematical interests and training predated his Italian years. This is evident, for example, in Steno's De musculis et glandulis observationum specimen (Copenhagen, 1664), where Steno had already developed an early geometrical theory of the muscles. ${ }^{19}$ But besides the muscles, there has been little historical work done on Steno's early interests in mathematics until now. ${ }^{20}$

The second historical implication of Steno's early interest in mathematics has to do with the development and spread of mixed mathematics into the discipline of anatomy in the second half of the seventeenth century. Steno's interests in mathematics developed gradually with his anatomical works, especially those on the glands. These works are representative of the new anatomical research of the 1660s, based not only on new dissection methods such as the regular prac-

${ }^{16}$ Bertoloni Meli, "The Collaboration between Anatomists and Mathematicians," pp. 696-706.

${ }^{17}$ Steno, De solido (Florence, 1669), p. 50; BOP, p. 802.

${ }^{18}$ Leopoldo de' Medici to Alessandro Segni, 27 November 1666, in Copenhagen, Royal Danish Library, Acc. 2019/54: “il S. Stenone Danese Anatomico gioviane d'età ma insigne nel suo mestiere corredato poi d'ogni sorte di laudazione, e geometra bravo il che molto li giova al suo mestiere et il vero tipo della modestia." Although some dated the letter April 1666, Leopoldo's handwriting says "Nov. 1666."

19 Troels Kardel, Steno: Life, Science, Philosophy (Copenhagen: The Danish National Library of Science and Medicine, 1994), pp. 25-32; Kardel, Steno on Muscles, pp. 11-16; Bertoloni Meli, "The Collaboration between Anatomists and Mathematicians," pp. 697-699.

20 The few works that mentioned Steno's research on the glands barely addressed any mathematics, see Harald Moe, "When Steno Brought New Esteem to Glands," in J. Poulsen and E. Snorrason (eds.), Nicolaus Steno 1638-16868: A Re-consideration by Danish Scientists (Gentofte, Denmark: Nordisk Insulinlaboratorium, 1986), pp. 51-96. For a brief mention of the mechanical aspect of Steno's study on glands see D. Bertoloni Meli, Mechanism, Experiment and Disease: Marcello Malpighi and Seventeenth-Century Anatomy (Baltimore: Johns Hopkins University Press, 2011), pp. 16, 103-6. 
tice of dissections and vivisections, but also on new areas of anatomical interest such as the glands, the lymphatic system, and the circulation of the blood. ${ }^{21}$ It was in this anatomical context that Steno used quantitative measurements, mechanical analogies, and the concepts of flow and speed in his anatomical argumentation. Some of these methods had already been used by other anatomists such as William Harvey, Santorio Santorio (1561-1636) and even Galen. ${ }^{22}$ For instance, Galen used the quantities of fluid drank (and later expelled) by a man to argue that urine was drawn directly from the blood. ${ }^{23}$ Yet, the epistemological role of mathematics was rapidly changing in the seventeenth century and, more importantly, it was still a matter of debate in natural philosophy and medicine. Therefore, a look at Steno's early uses of mathematics helps to see exactly how an early modern anatomist adopted such methods. This article's structure follows the chronological line of Steno's anatomical publications before the Elementorum myologice specimen, from 1661 to 1664 . For reasons of space, I focus mostly on the intellectual aspects of Steno's interest in mathematics, setting aside other considerations.

\section{WEIGHTS AND PROPORTIONS OF GLANDS, 1661}

Nicolaus Steno arrived in the Netherlands for the first time sometime before April $1660 .{ }^{24} \mathrm{He}$ had already studied for three years at the University of Copenhagen under Thomas Bartholin (1616-1680), one of the

\footnotetext{
${ }^{21}$ Frequent dissections and vivissections only became common in the second half of the $17^{\text {th }}$ century, see Anita Guerrini, The Courtiers' Anatomists: Animals and Humans in Louis XIV's Paris (Chicago: University of Chicago Press, 2015), pp. 6, 24; D. Bertoloni Meli, "Early Modern Experimentation in Live Animals" in Journal of the History of Biology, 46 (2013), pp. 199-226. These areas of interest expanded upon the two major discoveries of the late 1620s: the circulation of the blood by William Harvey and the lacteal vessels (the lymphatics) by Gaspare Aselli (1581-1625), whose works were often published together, see Domenico Bertoloni Meli, Mechanism, Experiment and Disease: Marcello Malpighi and Seventeenth-Century Anatomy (Baltimore: Johns Hopkins University Press, 2011), pp. 1-4, 31-7.

${ }^{22}$ For quantification and the use of concepts of flow by both Galen and Harvey see Michael Shank, "From Galen's Ureters to Harvey's Veins," Journal of the History of Biology, 18 (1985), pp. 331-55. For Galen's mechanical analogies see Bertoloni Meli, Mechanism, pp. 11-16. On Santorio and Harvey see Fabrizio Bigotti, "The Weight of the Air: Santorio's Thermometers and the Early History of Medical Quantification Reconsidered," Journal of Early Modern Studies 7 (2018), pp. 73-103; and Jerome Bylebyl, "Nutrition, Quantification and Circulation," Bulletin of the History of Medicine, 51 (1977), pp. 369-385.

${ }^{23}$ Owsei Temkin, "A Galenic model for quantitative physiological reasoning?" Bulletin of the History of Medicine. 35 (1961), pp. 470-475, esp. 471-472.

${ }^{24}$ Scherz's biography in BOP, p. 68.
}

leading physicians of Europe and a strong promoter of a new anatomy based in regular dissections. ${ }^{25}$ In those years, Steno became familiarized with the most recent anatomical findings, including the discovery of the circulation of the blood by William Harvey and the lymphatic vessels by Bartholin himself. ${ }^{26}$ In his third year, university classes were canceled due to a Swedish military siege imposed on Copenhagen, and so Steno used his time to read beyond the normal university curriculum, engaging with recent scientific literature associated with the new sciences, including some books related to mathematics. ${ }^{27}$ According to the notebook that he wrote in that year, Steno read in full Jean Pecquet's (1622-1674) Experimenta nova anatomica (Paris, 1654), a book which Pecquet wrote in collaboration with the French mathematicians Gilles Personne de Roberval (1602-1675) and Adrien Auzout (1622-1691), and he also read the original and long description of Pierre Gassendi's (1595-1655) mechanical and atomistic philosophy. ${ }^{28}$ When Steno left Denmark, although his intellectual commitment was to anatomy, he was aware of the new scientific trends flourishing throughout Europe.

Steno's years in the Low Countries confirm his commitment to anatomy. In those years, while still in his early twenties, Steno earned a solid reputation for his dissection skills among those who witnessed his dissections either in person or through his writings. ${ }^{29}$ Steno lived in Amsterdam from March to July 1660, where he took classes of anatomy with Gerard Blasius (1625-1682) and where he also observed for the first time the parotid salivary duct, later named as ductus stenonianus. ${ }^{30}$ Steno then moved to the University of Leiden, where his mentor Thomas Bartholin had also been twenty years before. ${ }^{31}$ There, Steno met the physicians Franciscus Sylvius (1614-1672) and Johannes Van Horne (1621-1670), old friends of Bartholin who were now prestigious pro-

\footnotetext{
${ }^{25}$ For more on Bartholi in English, see C. D. O'Malley, "Bartholin, Thomas," Complete Dictionary of Scientific Biography, vol. 1, pp. 482-3. ${ }^{26}$ Scherz's biography in BOP, pp. 47-50.

${ }^{27}$ For an overview of what Steno read, see Ziggelaar, "Commentary," in Ziggelaar (ed.), Chaos, pp. 459-481.

${ }^{28}$ Ziggelaar, "Commentary," pp. 473-474. On Pecquet and mathematicians see Bertoloni Meli, "The Collaboration between Anatomists and Mathematicians," pp. 670-7.

${ }^{29}$ Scherz's biography in BOP, pp. 72-83, 151, 367; Guerrini, The Courtiers' Anatomists, pp. 85-87.

${ }^{30}$ First named as such by Johannes Van Horne in Van Horne, Mikrokosmos seu brevis manuductio ad historiam corporis humani (Leiden, 1662), p. 23. See also Henry Gray, Anatomy of the Human Body, $20^{\text {th }}$ ed. (Philadelphia, Lea \& Febiger, 1918), p. 1134.

${ }^{31}$ Steno enrolled in the University of Leiden in 27 July 1660, see Leiden University Library, ASF 10, fol. 585; as quoted in Album studiosorum Academice Ludguno Batavee (The Hague, 1875), p. 482. For Bartholin in Leiden see O’Malley, “Bartholin, Thomas," p. 482.
} 
fessors of medicine and anatomy at the University. ${ }^{32}$ Under their guidance, Steno continued his explorations of the salivary duct and salivary glands. Upon the suggestion of Sylvius and Bartholin, Steno published his first anatomy book, the Anatomica disputatio de glandulis oris (Leiden, 1661), the outcome of a university dissertation defense at Leiden, presided by Van Horne. ${ }^{33}$ The book was published with the Elsevier printers, the same house that published Galileo's Two New Sciences (Leiden, 1638) a few decades earlier. In this short book, Steno put forward a full description of the salivary glands, the most complete up to then, in a time in which studies on the glands were emerging as a new area of anatomical research. ${ }^{34}$ Half a year later, Steno re-edited his text as the first part of a four-part book in 1662, the Observationes anatomicae (Leiden, 1662). This new book, which was distributed more widely, included Steno's research not just on the salivary, but also on the lachrymal and nasal glands. Although a single book, the four parts of the Observationes anatomicae show Steno's intellectual progress and how he gradually used more methods and ideas from the physico-mathematics, which he increasingly acknowledged.

This research program on the glands started when Steno observed for the first time the parotid salivary duct, first in a sheep's head and then in a dog. ${ }^{35}$ This duct proceeded directly from the parotid gland, located behind the ear, to the mouth. But the most recent book on glands, the Adenographia sive glandularum totius corporis descriptio (London, 1656), written by the English physician Thomas Wharton (1614-1673), had no mention of this duct. ${ }^{36}$ The Adenographia was the first anatomical publication entirely dedicated to glands, so studies of glands still had much to develop, as the works of Steno and Sylvius show. ${ }^{37}$ Wharton described the parotid

\footnotetext{
32 Bartholin participated in Sylvius' dissections around the year 1640 , see Johannes Walaeus letter to Thomas Bartholin, 10 October 1640 in T. Bartholin, Institutiones anatomicae (1641), p. 408. Van Horne wrote the letter "De aneurysmate epistola" published in Thomas Bartholin, Anatomica aneurysmatis dissecti historia (Palermo, 1644).

${ }^{33}$ Nicolaus Steno, Observationes anatomicae quibus varia oris, oculorum, et narium vasa describuntur (Leiden, 1662), p. 5 (BOP, p. 430).

${ }^{34}$ Bertoloni Meli, Mechanism, Experiment and Disease, pp. 103-106.

${ }^{35}$ Steno to Bartholin, 22 April 1661, in Bartholin, Epistolarum Medicinalium Centuria III (Copenhagen, 1667), pp. 88-89: "quod 7 April mihi emptum in Museolo solus secabam ovillo capite ductum, à nemine, quod sciam, descriptum invenirem. ... et paucis inde diebus in canino capite licet obscurius successit." (BOP, pp. 420-421). For this research of the parotid duct Steno also dissected a lamb, a cow, many more dogs, rabbits and he mentioned Sylvius' dissections of human cadavers at the hospital, see Steno, Observationes anatomicae, $\$ 16, \$ 18, \$ 47-48, \$ 50$, $\$ 19$, pp. 15, 17, 46-47, 49, 18-19 (BOP, pp. 436, 438, 457-458, 460, 439).

${ }^{36}$ For an English translation see Stephen Freer (transl.), Thomas Wharton's Adenographia (Oxford: Oxford University Press, 1996).

${ }^{37}$ Andrew Cunningham, "The historical context of Wharton's work on
}

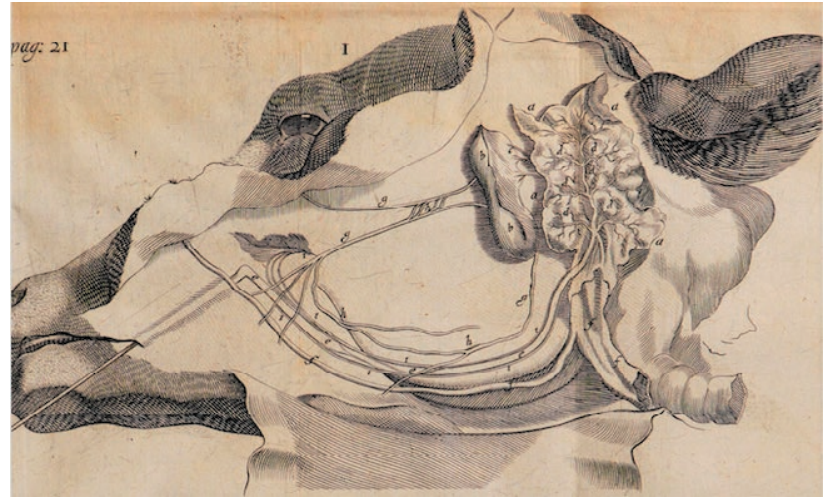

Figure 2. Parotid glands in the head of a calf. a) the largest is the conglomerate gland with c) the salivary duct, and b) the beanshaped conglobate gland. From Steno, Observationes anatomicae (Leiden, 1662), p. 21. Courtesy of Wellcome Collection.

gland in detail, but he did not relate it to the production of saliva because, as Steno explained, he saw no salivary duct. ${ }^{38}$ For Wharton, saliva was produced only in the maxillary glands, where he observed a pathway between them and the mouth, now called ductus whartonianus. ${ }^{39}$

But there were other things that Wharton missed. According to Steno, the parotid gland described by Wharton was actually formed by two distinct glands, the conglobate parotid gland, connected to the lymphatic system, and the conglomerate parotid gland, connected to the mouth via the salivary duct (fig. 2). ${ }^{40}$ Here, Steno was following the twofold division between conglobate and conglomerate glands, developed by his professor Franciscus Sylvius. ${ }^{41}$ The conglobate glands were round organs directly connected to the lymphatic vessels, and the conglomerate were larger organs that released fluids into the body, such as salivary or the pancreatic fluids. Although Sylvius explained this distinction in his writings, Steno said he learned it directly from his professor's dissections at the hospital in Leiden, where "medical practice" was taught "daily."

the glands," in Thomas Wharton's Adenographia (Oxford, 1996), pp. xxvii-xxxi.

${ }^{38}$ Steno, Observationes anatomicae, p. 15: "sed non mirum haec à Clarissimo viro proposita, quandoquidem praeter vasa cæteris partibus communis nihil in illa observavit." (BOP, p. 437); Thomas Wharton, Adenographia (London, 1656), pp. 124-7.

${ }^{39}$ See Steno, De musculis et glandulis (Copenhagen, 1664), p. 40; Gray, Anatomy of the Human Body, p. 1135.

${ }^{40}$ Steno, Observationes, $\$ 10$, p. 10: "Ut itaque distinctè considerentur, poterit hæc de qua nobis sermo est, parotis conglomerata appellari, nomine conglobatarum parotidum reliquis relicto." (BOP, p. 433).

${ }^{41}$ Steno, Observationes anatomica, $\$ 9$, p. 7 (BOP, p. 432); Bertoloni Meli, Mechanism, Experiment and Disease, p. 103.

${ }^{42}$ Steno, Observationes anatomica, $\$ 10$, p. 9: "Superiori enim anno iam præcipite, cùm in Nosocomio praxin faciendo quotidie doceret Clariss. 
To show better Wharton's mistake, instead of arguing on the basis of dissections alone, Steno put forward another argument using quantitative measurements. For some glands, including the maxillary and the parotid glands, Wharton registered their weights in different animals (table 1). The proportions between the weights of the two glands measured by Wharton in a man and in a fetus of a cow were somewhat similar, averaging approximately 0.6 . This proportion showed that the parotid had almost twice the weight of the maxillary glands. However, Steno argued that the parotid glands were not as heavy as Wharton thought, mainly because they were two separate glands, the conglobate and the conglomerate. Steno said that in Wharton's case the proportion between the parotid and maxillary glands

has not been exactly observed ... [unless] besides bigger and more numerous nerves reported through the upper gland, the smaller [conglobate] gland enclosed in the larger [conglomerate gland] increased the weight of the latter, insofar as it was [thought to be] not distinct from the other. ${ }^{43}$

To show better his point, Steno measured the weights of the glands in a calf he dissected. This time, however, the parotid gland was "free from vessels and from the conglobate gland lying beside it." ${ }^{\prime 4}$ In the end, Steno's proportion of the weights of the maxillary and the parotid conglomerate glands was 0.89 , much closer to 1 , thus meaning that their weights did not differ much. Neither Steno nor Wharton wrote the precise proportion in a structured format like table 1, but they both referred to it. ${ }^{45}$ More importantly, with this measurement Steno used a quantitative argument to confirm his point on the separation of the conglobate and conglomerate parotid glands, which Wharton missed. Since by definition conglomerate glands secreted a fluid and Steno had found a salivary duct coming out of it, this quantitative point also had an implication on the function of the glands and thus contributed to Steno's argument that the parotid conglomerate gland produced salivary fluid.

For a modern scientist, it could be tempting to judge Steno and Wharton for drawing conclusions on these proportions without enough comparative data, i.e. for lacking what modern science now understands

Franciscus Sylvius exhibuit tum discipulis..." (BOP, p. 433).

${ }^{43}$ Steno, Observationes, $\$ 12$, p. 11: "Ne tamen huius ad illam proportionem exacte observatam esse credam, suadet, præter nervos majores copiosioresque per superiorem delatos, minor majori inclusa glandula, quam, utpote a reliqua non distinctam, pondus illius auxisse puto." (BOP, p. 434).

${ }^{44}$ Steno, Observationes, $\$ 12$, p. 11: “à vasis et sibi apposita conglobata liberatam" (BOP, p. 434).

${ }^{45}$ Steno, Observationes, $\$ 12$, p. 11: “proportione exactè observatam.”
Table 1. Data from Wharton, Adenographia, pp. 119-120, 125 and Steno, Observationes, pp. 10-11. The conversion of units from $17^{\text {th }}$-century ounces to grams is from Wilhelm Maar (ed.), Nicolai Stenonis Opera Philosophica, 2 vols. (Copenhagen: Vilhelm Tryde, 1910), vol. 1, pp. 227-228.

Dissected corpses Maxillary Gland Parotid Gland Proportion

28-year-old man

$\begin{array}{llll}\text { (Wharton) } & 9.8 \mathrm{~g} & 17.6 \mathrm{~g} & 0.56\end{array}$

fetus of a cow

(Wharton)

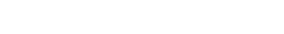

0.67

\begin{tabular}{c|ccc} 
& \multicolumn{3}{c}{ proportion average for Wharton's } \\
values & $\mathbf{0 . 6 2}$ \\
calf (Steno) & $125 \mathrm{~g}$ & $141 \mathrm{~g}$ & $\mathbf{0 . 8 9}$ \\
\hline
\end{tabular}

as observational error. ${ }^{46}$ However, in the middle of the seventeenth century, when the epistemological value of experiments was still being debated, there was nothing akin to a statistical theory of error. ${ }^{47}$ In fact, notions of how to perform experiments, and how to report them, were even evolving between Steno and Wharton themselves. Both authors decided to measure and compare the weights of the glands, but there were significant differences in their approaches. First, Steno pointed out that Wharton's quantitative data was not precise enough, since Wharton did not say what exactly he had weighed: was it the glands and the attached vessels, or did he remove blood vessels and nerves from the glands beforehand? In Steno's words, Wharton "seems to have described an abundance of matter from these glands in an undetermined quantity [extensione non determinata]." 48 This remark also conveys Steno's understanding of a need to describe the experimental conditions better. Steno tried to improve upon Wharton, by saying he detached each gland that he

${ }^{46}$ Stephen Stigler, The History of Statistics: The Measurement of Uncertainty before 1900 (Cambridge, MA: Harvard Univ. Press, 1986), esp. 90-1; Lorraine Daston, Classical Probability in the Enlightenment (Princeton, NJ: Princeton University Press, 1988), esp. 271-2; Ian Hacking, The Emergence of Probability: A Philosophical Study of Early Ideas About Probability Induction and Statistical Inference, 2nd ed. (Cambridge: Cambridge University Press, 1975, 2006), p. 130.

${ }^{47}$ For seventeenth-century debates on experiments see Steve Shapin and Simon Schaffer, Leviathan and the Air Pump: Hobbes, Boyle, and the Experimental Life (Princeton: Princeton University Press, 1985), esp. 225-282; Dear, Discipline and Experience, pp. 63-85. For the historical value of approaches that would today be considered wrong see Jed Buchwald and Allan Franklin (eds.), Wrong for the Right Reasons (Dordrecht: Springer, 2005).

${ }^{48}$ Steno, Observationes anatomica, $\$ 12$, pp. 10-11: "Quibus Clariss[imus] Vir copiam materiæ expressisse videretur, extensione non determinata, nisi jam ante constare putasset, materiam in utraque eodem modo esse dispositam, quod \& innuit, dum substantiam utrique similem adscribit." (BOP, p. 434). 
weighed "from vessels and from the conglobate gland lying beside it." ${ }^{\text {"9 }}$ Finally, whereas Wharton presented the weights only as a secondary detail of his anatomical description, Steno used them to argue for the existence of two glands - the conglobate and conglomerate glands. Ultimately, in Steno's text, the careful description of how he carried out the measurements and the details he included lent them a greater epistemological value than they had for Wharton.

Steno did not use more quantitative measurements in the Observationes, but he resorted to other mathematical approaches. ${ }^{50}$ After establishing the distinction between the conglobate and conglomerate parotid glands, Steno explained that the function of the latter was to produce the salivary fluid, alongside the maxillary glands, already discovered by Wharton. ${ }^{51}$ In fact, Steno discovered other glands that produced saliva and he listed five types in total: parotid glands, maxillary glands, sublingual glands, palatine glands and glands of the cheek. ${ }^{52}$ Although Steno did not comment on the fluid production rates each gland, he said that "several small vessels in the mouth" transmitted "fluid equally to all parts [ad humorem omnibus ceqaliter communicandum]. ${ }^{53} \mathrm{He}$ concluded that the fluid reached all parts equally "in order that the upper parts moisten as well as the lower ones, [and] the internal as well as the external ones." ${ }^{\prime 4}$ Later, when discussing the constitution of the saliva, which Steno said required "chymical anatomy," he used the same kind of discourse, in which he spoke of a quantifiable entity without actually measuring it. ${ }^{55}$ First, he said that "tasting and smelling" saliva was similar to water because it was "deprived of quality," however "seeing and feeling [it] judge it less simple than water." ${ }^{\text {" }}$ Again, Steno was following the methods of his

\footnotetext{
${ }^{49}$ Steno, Observationes, $\$ 12$, p. 11: "à vasis et sibi apposita conglobata liberatam" (BOP, p. 434).

${ }^{50}$ Wharton, on the other hand, did include more measurements, as when he said that the maxillary duct in a cow was thirteen inches long, see Wharton, Adenographia, p. 131: "ductu tredecim pollices longo provehitur"

${ }^{51}$ Steno, Observationes, $\$ 17$, p. 17: "Verus Parotidum conglomeratarum usus, illam, quæ per ductum salivarem exteriorem in exteriorem oris cavitatem excernitur, salivam præparare..." (BOP, p. 438)

${ }^{52}$ See Steno, Observationes anatomica, $\$ 9$, p. 8 (BOP, p. 432). For a description of the cheek, sublingual and palatine glands, see idem, $\$ 18$, $\$ 20, \$ 21$, pp. 17-23 (BOP, pp. 438-440).

${ }^{53}$ Steno, Observationes anatomica, $\$ 22$, p. 22: "plura data sunt vascula ad humorem omnibus æqualiter communicandum" (BOP, p. 440).

${ }^{54}$ Steno, Observationes, $\$ 22$, p. 22 : “Ut autem in ore cum inferioribus superiora, interiora cum exterioribus madefierent" (BOP, p. 440)

${ }^{55}$ Steno, Observationes, $\$ 25$, p. 24: "consideratio Chymicam Anatomen requirat" (BOP, p. 441).

${ }^{56}$ Steno, Observationes, $\$ 28$, p. 26: "Quam itaque sapor, et odor átrotov iudicant, eam visus, et tactus aqua minus simplicem decernunt" (BOP, p. 444).
}

professor Franciscus Sylvius who relied strongly on the senses as a source of information about the constitution of chymical substances. ${ }^{57}$ Indeed, Steno concluded that saliva was not "a simple liquid, but a mixed one, and this in a proportion [singulari proportione]." ${ }^{58}$ But this proportion was discussed only in qualitative terms, even by "the famous Sylvius ... [who] thinks that in saliva there is much water, a little volatile spirit and very little lixivial salt mixed with, and moderated by a trace of oil and spirit of acid." 59

\section{THE MECHANICAL ACTION OF BODILY FLUIDS, 1661-1662}

Steno finished the 1661 version of his treatise on the salivary glands with a set of corollaries on the role of the mind on blood circulation, on the glands of the nose and on the filtering of blood in the body, which he expanded in the other treatises of the Obsevationes anatomicae. ${ }^{60}$ Corollaries were a structure most common in mathematical treatises, usually associated with Euclid's Elements, but also typical of academic dissertations. ${ }^{61}$ Steno did not use a corollary structure in the Observationes, as he would later do in his final book on the muscles. But in its third treatise, on the lachrymal glands, Steno became much more open when speaking about mechanics and using mathematical concepts. First, he dedicated the third treatise to six intellectuals from the Low Countries and Denmark, two of them mathematicians. ${ }^{62}$ One was Jorgen Eilersen (Georgius Hilarius) (1616-1686), a Danish theologian who graduated from the University of Copenhagen and the headmaster of the Latin School of Copenhagen, which Ste-

${ }^{57}$ Evan Ragland, "Chymistry and Taste in the Seventeenth Century: Franciscus Dele Boë Sylvius as a Chymical Physician Between Galenism and Cartesianism," Ambix 59 (2012), pp. 1-21. On the use of the word "chymistry" see Lawrence Principe, The Secrets of Alchemy (Chicago: University of Chicago Press, 2013), p. 85.

${ }^{58}$ Steno, Observationes anatomicae, $\$ 28$, p. 27 : "Esse iitaque non simplicem liquorem, sed mixtum, idque singulari proportione, ex ante dictis patet." (BOP, p. 445).

${ }^{59}$ Steno, Observationes anatomica, pp. 27-28: "Clarissimi Sylvius ... existimat esse in saliva multum aquæ, parum spiritus volatilis, et minimum salis lixiviosi, cum olei spiritusque acidi tantillo misti, temperatique." (BOP, p. 445). F. Sylvius, Opera medica, hoc est, disputationum medicarum decas (Geneva, 1681), p. 11.

${ }^{60}$ Steno, Disputatio de glandulis oris (Leiden, 1661) (BOP, pp. 462-463).

${ }^{61}$ For the use of corollaries in Dutch seventeenth-century dissertations, see Dirk Van Miert, Humanism in an Age of Science: The Amsterdam Athencum in the Golden Age, 1632-1704 (Leiden: Brill, 2009), p. 153-6. For an extensive study of dissertations in the early modern period, see Kevin Chang, "From Oral Disputation to Written Text: The Transformation of the Dissertation in Early Modern Europe," History of Universities 19 (2004), pp. 129-187.

${ }^{62}$ Steno, Observationes anatomica, pp. 80-81 (BOP, p. 483). 
no attended before the university. ${ }^{63}$ Although Eilersen was academically trained in theology, he wrote several books on mathematics in Copenhagen, where he also edited astronomical calendars and almanacs. ${ }^{64}$ In fact, Steno addressed him as a "mathematician and man of letters." 65 Eilersen was later appointed as Professor of Mathematics at the University of Copenhagen. ${ }^{66}$ The other mathematician was Jacob Golius (1596-1667), professor of mathematics at the University of Leiden since $1629 .{ }^{67}$ Steno was friends with Golius, since they discussed topics besides anatomy or mathematics, as when Golius informed Steno about the emergence of fevers in Amsterdam in September 1661. ${ }^{68}$ Golius also "did not disdain either to watch when I [Steno] prepared the salivary and lacrimal ducts in a calf," showing that he sometimes attended Steno's dissections. ${ }^{69}$

In this third treatise of the Observationes, Steno explained the production of tears in the eye glands and how they move from the glands to the eyes. But before starting his main narrative description of the lachrymal glands, Steno wrote an introduction where he points out the importance of lubrication in mechanical motion. He explains that those who work on mechanics know that, "to facilitate movement, the things to be moved should be smeared by some oily humor." ${ }^{70}$ He compares the oil to a third agent that facilitates the mover, like pushing a boat over a surface with the help of rollers laid underneath (fig. 3) or "smearing with an unctuous fluid the axle about which the wheel rotates." ${ }^{11}$ Like these mech-

${ }^{63}$ Gustav Scherz's biography in BOP, pp. 29-31. On Eilersen see S. M. Gjellerup, "Eilersen, Jorgen" in Carl Frederik Bricka (ed.), Dansk biografisk Lexikon (Copenhagen, 1887-1905), vol. 4, pp. 464-465; and Maar, Nicolai Stenonis Opera Philosophica, vol. 1, p. 241.

${ }^{64} \mathrm{~J}$. Eilersen, Trigonometria plana (Copenhagen, 1644); Eilersen, Progymnasmatum mathematicorum enchiridion (Copenhagen, 1656).

${ }^{65}$ Steno, Observationes anatomicee, p. 80: "D. Georgio Hilario, Mathematico et Literatori" (BOP, p. 483).

${ }^{66}$ For Eilersen's university appointment see Gjellerup, "Eilersen, Jorgen."

${ }^{67}$ W. Juynboll, "Golius, Jacob," in P. C. Molhuysen and P. J. Blok (eds.), Nieuw Nederlandsch Biografisch Woordenboek, 10 vols. (Leiden, 19111937), vol. 10 (1937), pp. 287-289; and "Golius, Jacobus" in A. J. van der Aa (ed.), Biographisch woordenboek der Nederlanden, 21 vols. (Haarlem, 1852-1878), vol. 7, pp. 270-3.

${ }^{68}$ Steno to Thomas Bartholin, 12 September 1661, in Thomas Bartholin, Epistolarum Medicinalium Centuria III (Copenhagen, 1667), p. 230: "et retulit mihi ante paucos dies Clariss. Golius sibi à Medicó quos dam Amstelodamensi per litteras relatuum...” (BOP, p. 468).

${ }^{69}$ Steno, Observationes anatomice, p. 59: "Sed nec Clariss. Golius Mathematum et Orient. Ling. Profess. Præceptor colendus cum salivæ et lachrimarum vasa in bubulo adornarem, spectatorem agere dedignatus est." (BOP, pp. 470-1)

${ }^{70}$ Steno, Observationes anatomicae, p. 85: "ut ad motum faciliorem reddendum res movendas humore unctuoso oblinerent" (BOP, p. 484).

${ }^{71}$ Steno, Observationes anatomicae, p. 85: "Viderunt illi, si movendum inter et fixum, super quod motus fieri debet, tertium motu facilius intercedat, opus longe commodius procedere, hinc, ut suppositis cylindris in æquora navem propellunt, sic et, super quem rota volvitur,

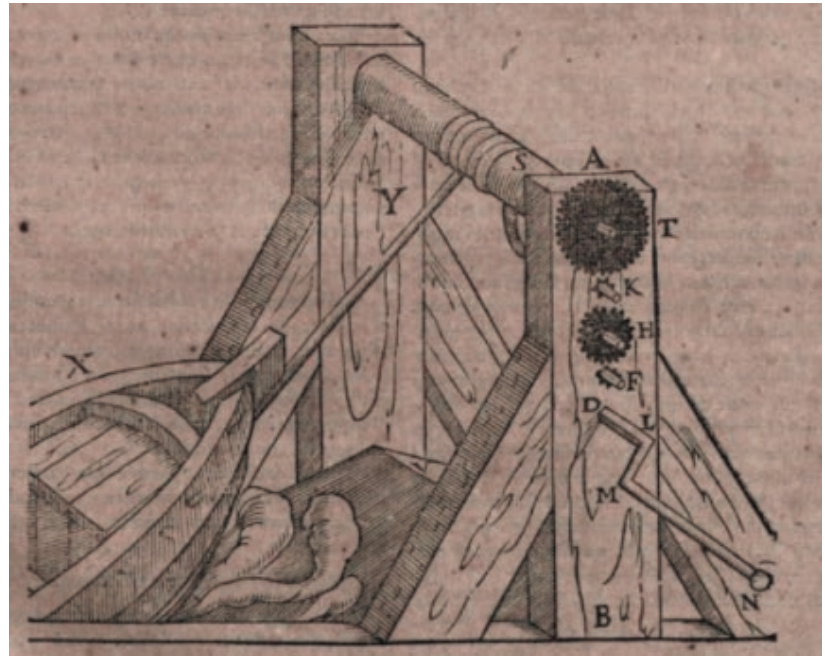

Figure 3. Pulling a boat over a flat surface with the help of rollers laid underneath from Simon Stevin, Les Euvres Mathématiques (Leiden, 1634), p. 481. Courtesy of Special Collections, The Sheridan Libraries, Johns Hopkins University.

anisms, Steno continues, the bodies of animals also rely on fluids to make the parts move better. But, unlike machines, the living body "proceeds more skillfully or, I should say, more divinely," because "both the fluid that is supplied and the quantity in which it is supplied show a skill far greater." ${ }^{2}$ According to him, this was seen in the mouth with salivary fluid's enhancement of the movements of the mouth, but most especially in the eyes. $^{73}$

The analogy between artificial mechanisms and the human body in the works of Steno and other scholars is often attributed to the widespread influence of Cartesian thought, especially in the Netherlands. ${ }^{74}$ How-

polum liquore pinguiori inungentes gyrationem facilius expediunt." (BOP, p. 485).

${ }^{72}$ Steno, Observationes anatomicae, p. 86: "In automatico autem animalium corpore artificiosius, imo divinius hæc omnia geruntur; ibi enim et humor, qui subministratur, et, quo subministratur, modus longe maius artificium commonstrant."

${ }^{73}$ Steno, Observationes anatomicae, p. 86: "Sic partium in ore motus accedente saliva promoventur... Sed præ cæteris in oculis elegantissimè hæc conspiciuntur." (BOP, p. 486).

${ }^{74}$ Eric Jorink says that the Netherlands was "the hotbed" of Cartesian philosophy, in "Modus politicus vivendi: Nicolaus Steno and the Dutch (Swammerdam, Spinoza and Other Friends), 1660-1664," in Raphael Andrault and Mogens Lærke, Steno and the Philosophers (Leiden: Brill, 2018) pp. 12-44, esp. 16; see also Wiep van Bunge, "The Early Dutch Reception of Cartesianism" in Steven Nadler, Tad M. Schmaltz, Delphine Antoine-Mahut, The Oxford Handbook of Descartes and Cartesianism (Oxford: Oxford University Press, 2019); G. A. Lindeboom, "The Impact of Descartes on Seventeenth Century Medical thought in the Netherlands," Janus, 58 (1971), pp. 201-206. For the supposed influenced of Cartesianism on Steno, see Sebastian Olden-Jørgensen, "Nicholas Steno and René Descartes: A Cartesian perspective on Steno's sci- 
ever, there was already a tradition of using mechanical analogies in anatomy since Galen and Erasistratus. ${ }^{75}$ Thomas Wharton, no Cartesian himself, also relied on mechanical analogies, as when he compared a muscle in the mouth to a pulley. ${ }^{76}$ There were, however, conceptual differences in the way anatomists adopted these analogies. For instance, like Steno, Galen also commented on the body as superior to machines, but he did it mostly to show that mechanical analogies fell short of the full anatomical reality. ${ }^{77}$ Steno explained that the body differed from a machine not in the mechanism itself but in "the humour which is supplied," which reveals "a skill far greater." 78

But there is more to be said about these mechanical analogies beyond the typical Cartesian comparison of bodies to machines. Mechanics was considered part of physico-mathematics. Thus, in Steno's mind, those who studied and practiced mechanics, the "mechanici" as he called them, relied on mathematics as their main tool to describe the natural world..$^{79}$ Steno in particular had in mind the work of "the most talented [Simon] Stevin," one of the leading names of Dutch mathematics, and whom Steno mentioned in the preface. ${ }^{80}$ In the seven-

entific development," Gary Rosenberg (ed.), The Revolution in Geology from the Renaissance to the Enlightenment (The Geological Society of America, 2009), pp. 149-57; and Stefano Miniati, Nicholas Steno's Challenge for Truth (Milan: Franco Angeli, 2009), p. 95.

${ }^{75}$ Evan Ragland, "Mechanism, the Senses, and Reason: Franciscus Sylvius and Leiden Debates Over Anatomical Knowledge After Harvey and Descartes," in Peter Distelzweig, Benjamin Goldberg and Evan Ragland (eds.), Early Modern Medicine and Natural Philosophy (New York: Springer, 2016), pp. 173-206, esp. 183-4.

${ }^{76}$ Wharton, Adenographia, p. 131: "fertur sub musculo maxillari tereti biventri, ..., qui eidem ramo quasi trochlea vicem præstat." On Wharton as non-Cartesian see Cunningham, "The historical context of Wharton's work on the glands," p. xli; Wharton, Adenographia, p. 154: "Hanc opinionem primus proposuit Cartesius, Lib. de affect. art. 31,32 eamque variis rationibus Bartholinus expugnavit, nempe: ..."; and Wharton letter to Mrs. Church, 15 May 1673, in Wharton, Thomas Wharton's Adenographia, p. 311.

${ }^{77}$ Sylvia Berryman, "Galen and the Mechanical Philosophy," Apeiron 35 (2011), pp. 235-53, esp. 242-7.

${ }^{78}$ Steno, Observationes, p. 86: "In automatico autem animalium corpore artificiosiùs, imò divinius hæc omnia geruntur; ibi enim et humor, qui subministratur, et, quo subministratur, modus longè maius artificium commonstrant." (BOP, p. 486). Interestingly, even Descartes nuanced his body-machine comparisons, see Gideon Manning, "Descartes' Healthy Machines and the Human Exception," in Daniel Garber and Sophie Roux (eds.), The Mechanization of Natural Philosophy (Dordrecht: Springer, 2013), pp. 237-62.

${ }^{79}$ Steno, Observationes, p. 85: "Quod Mechanicos usus docuit..."

${ }^{80}$ Steno, Observationes, p. 82: "Existimat ingeniosissiimus Stevinus" (BOP, p. 484). For more on Stevin see E. J. Dijksterhuis, "The Life and Works of Simon Stevin," in E. J. Dijksterhuis (ed.), The Principal Works of Simon Stevin, Vol. 1: General Introduction, Mechanics (Amsterdam, 1955), pp. 3-14; Dirk Struik, The Land of Stevin and Huygens: A Sketch of Science and Technology in the Dutch republic during the Golden Century (London: D. Reidel Publishing Company, 1981), esp. 52-60. teenth century, one of the main arguments for the study of mechanics was the command it gave its practitioners over phenomena whose operations were marvelous and unseen, like the use of a lever to lift weights that were impossible to lift otherwise. This description fits well with Steno's understanding of the human body, which he described as even more marvelous than inert mechanisms, as we saw. By adopting mechanical analogies, like Descartes and others had done, Steno was looking for an approach to make the invisible operations of the human body visible. Jesuit scholars such as Athanasius Kircher and Gaspar Schott (1608-1666), whom Steno read in his final year in Copenhagen, also used physico-mathematics to unmask the hidden phenomena of nature ${ }^{81}$ Steno returned to this idea of using mathematics to illustrate hidden phenomena in his preface to the Elementorum myologice specimen, where he insisted that, by neglecting mathematics, "anatomy has brought the matter to such a point that nothing remains more unknown to man than man himself." 82

\section{SPEED AND FLOW OF BLOOD, TEARS, AND SALIVA, 1662}

Steno gestured towards mathematical concepts one more time in his explanation of how the eye glands produced lachrymal fluid. As typical in an anatomical treatise, Steno begins by describing the structure of the glands, agreeing with Wharton's description of the two conglomerate glands of the eye, which they both called the lachrymal and innominate glands. ${ }^{83}$ But when addressing the function of the glands, Steno explains, Wharton and others "did not believe that such an abundance of tears can possibly come forth from such small glands." ${ }^{4}$ In fact, the large quantity of tears that often come to the eye led Wharton to agree with Hippocrates

\footnotetext{
${ }^{81}$ Steno has many notes related to Kircher, but for reference to Kircher and Schott in the same place see Ziggelaar, Chaos, pp. 253-4. For Kircher and Schott's approach to hidden phenomena, see Mark Waddell, Jesuit Science and the End of Nature's Secrets (Burlington, VT: Ashgate Publishing Company, 2015), esp. 5-15, 161-186.

82 Steno, Elementorum myologice specimen, p. iv: "Namque dum legitimi principis [mathematicarum] imperium non agnoscens, suo, ... eò rem [anatome] tandem deduxit, ut homine nihi homini manserit ignotius." (BOP, p. 651).

${ }^{83}$ Steno, Observationes anatomicae, pp. 86-87: "Glandulæ autem interiorem palpebrarum superficiem humectantes binæ sunt: lacrymis altera Clariss. Whartono innominata dicta ..."

${ }^{84}$ Steno, Observationes anatomica, p. 92: "non enim [magni viri] crediderunt, posse ex tam parvis glandulis tantum lacrymarum copiam prodire" (BOP, p. 490). Wharton, Adenographia, p. 178: "Enim verò hæ glandulæ perexiguæ sunt, et multum humiditatis in se coacervare nequeunt, nè vicesima quidem lachrymarum partem quæ tantillo temporis spacio a nonnullis profunduntur."
} 
that tears were produced in the brain. ${ }^{85}$ Not only was the brain the largest organ closer to the eye, but, in humans, tears were also related to emotions and pain, felt mainly by the brain and the nervous system. ${ }^{86}$ Steno, however, describes both eye glands as conglomerate glands, and so, according to his theory of glands, they produce a fluid, which serves to lubricate the eye or, when produced "profusely... it comes under the name of tears." To address the problem of quantity, Steno uses a simple mathematical explanation, by saying that

if the magnitude of the [tear]drops is compared to the time during which they are formed, no problem will appear here. For the time is not so short that as much humor could not flow in through several vessels as is required to form a drop. ${ }^{88}$

Steno uses the concepts of time and flow to say that the formation speed of tears is slow enough to produce each tear drop. Later in the same treatise, Steno uses these concepts to put forward a mechanical theory of glandular secretion by blood filtration.

Steno had already suggested that the salivary glands produced saliva directly from the blood, and not, as Wharton claimed, from the nerves. ${ }^{89}$ In the first treatise, Steno said that "arteries supply to the glands, besides heat, also nutriment and together with it the matter of saliva." ${ }^{90}$ Wharton thought that was unlikely, because there were not sufficient arteries and veins passing through the maxillary glands for "the quantity

\footnotetext{
${ }^{85}$ Wharton, Adenographia, pp. 181: "Ego existimo esse nervos, præcipuè illos, qui decurrentes per plexum retiformem, in eum, ut dixi, copiosas cerebri humiditates effundunt, ex eóque penu sufficientem oculis materiam miniftrant." Elizabeth Craik, "The Reception of the Hippocratic Treatise On Glands" in M. Horstmanshoff, H. King and C. Zittel (eds.), Blood, Sweat and Tears - The Changing Concepts of Physiology from Antiquity into Early Modern Europe (Leiden: Brill, 2012), pp. 65-82, esp. 66.

${ }^{86}$ On emotional tears as specific to humans see Steno, Observationes anatomicae, p. 92: "et sequeretur, etiam brutis attribuendas lacrymas, quod multis absurdum videtur." (BOP, p. 490). On the brain as the center of the nervous system, an idea held by most Ancient writers, see Vivian Nutton, Ancient Medicine, 2nd ed. (New York: Routledge, 2004, 2013), pp. 118, 134, 238-240.

${ }^{87}$ Steno, Observationes anatomicae, p. 90: "modò impetuosius profluens lacrymarum nomine venit" (BOP, pp. 488).

${ }^{88}$ Steno, Observationes anatomicae, p. 92: "si guttarum magnitudo cum tempore, quo colliguntur, conferatur, nulla hic videbitur difficultas. Nec enim tempus adeo breve, quin per plura vasa tantum humoris affluere possit, quantum ad guttam constituendam requiritur;" (BOP, p. 490).

${ }^{89}$ Wharton, Adenographia, p. 134: "Proximo loco inquirendum, est è quibusnam partibus et perquas vias hic humor in glandulas salivales derivetur. Credibile est, è nervoso genere profundi."

${ }^{90}$ Steno, Observationes anatomicae, $\$ 38$, p. 35 : "Ex prædictis itaque facilè liquet, arterias glandulis, præter calorem, etiam nutrimentum, et simul salivæ materiam suppeditare." (BOP, p. 449).
}

of salivary matter that is excreted." ${ }^{11}$ In order to solve this problem, Steno said that "since saliva does not flow into the mouth with the same speed [celeritate] at which blood arrives, the delay of the saliva in its flowing could compensate the paucity of blood arriving more quickly." ${ }^{\prime 2} \mathrm{He}$ explored this idea further in his study of the eye glands. According to him, the glands of the eye do not have to be as large because "all the humor which emanates from the eyes was [not] collected previously in the glands." ${ }^{93}$ For Steno, the secretion of lachrymal humor is in fact directly associated with each pulsating passage of arterial blood. As blood flowed normally through the eyes, the glands produce the quantity of lachrymal fluid necessary to keep the eyes normally lubricated. ${ }^{94}$ But for a larger production of tears, Steno argues that disturbances in the blood flow - such as the ones caused by strong emotions - were the main cause, since some components of the blood would feel pressured to follow other paths like "the simple and porous tunics of the capillaries present inside the glands." 95 The particles [partes] of this humor that leave the blood into the glands, which he calls "serum," "enter with greater speed, as they naturally tend to, so that the speed compensates for the transit through the narrow vessels." 96 Therefore, Steno concludes that the increasing speed of blood filtration alone produces "great abundance of tears."

The speed and flow of blood had also been critical in William Harvey's discovery of the circulation of blood. Harvey decided to calculate the amount of blood ejected at each forceful systole of the heart. ${ }^{98}$ His results made him realize that "in a comparatively short space of time the whole of the blood contained in the body must pass

91 Wharton, Adenographia, p. 136: “Denique, maior est quantitas materiæ salivalis per has glandulas excretæ, quam facile credas ab exiguis illis arteriis et venis quæ ad has partes distribuuntur."

${ }^{92}$ Steno, Observationes anatomicae, $\$ 37$, p. 34: “Cum enim eadem celeritate, qua sanguis accedit, in os non influat saliva, poterit mora, quam hæc in fluxu suo trahit, illius celerius affluentis paucitatem compensare." (BOP, p. 449).

${ }^{93}$ Steno, Observationes anatomicae, p. 92: "Nec, qui ex oculis emanat, humor, totus in glandulis antea fuit coacervatus." (BOP, p. 490).

${ }^{94}$ Steno, Observationes anatomicae, p. 91: "Existimo itaque, manifestum satis esse, illum saltem humorem, qui motui palpebrarum inseruit, ex arterioso sanguine in glandulis secretum per descripta modo vasa adferri." BOP, p. 489).

95 Steno, Observationes anatomicae, p. 94: "eo copiosius per simplices et porosas capillarium intra glandulas existentium tunicas exprimetur serum;" (BOP, p. 491).

${ }^{96}$ Steno, Observationes anatomicae, p. 94: "quicquid per alias vias egredi aptum est, ingreditur illas maiori, ac naturaliter solet, celeritate, ut ita viarum angustiam transitus celeritas compenset;" "hi meatus non dilatentur." (BOP, p. 491).

${ }^{97}$ Steno, Observationes anatomicae, p. 94: "celeritas majori lacrymarum copiæ producendæ sufficit.” (BOP, p. 491).

98 William Harvey, Exercitatio anatomica de motu cordis (Frankfurt, 1628), chapter 9. 
through the heart," and so the blood had to be in circulation. ${ }^{99}$ However, according to historian Roger French, this quantitative method was very rough, and "far less precise than those of Sanctorius and van Helmont."100 Yet, the point is that neither Harvey nor Steno were looking for precision in these cases, but only to show the role of quantities in blood circulation. ${ }^{101}$ In Steno's case it was the changing speed of the circulation that mattered for the production of tears. Steno went on to explain where exactly in the blood system these changes occurred and how the mind affected it, saying that it involved the muscles around the heart. ${ }^{102}$ It was from this early research using quantification and applying notions from mechanics to anatomy that Steno began to study muscle physiology, a topic which would remain central in his future anatomical research.

\section{MECHANISM AND GEOMETRY IN THE MUSCLES, 1662-4}

Steno was able to direct his research from the discovery of the salivary duct in the parotid gland to the most relevant topics of anatomy at the time, first to the lymphatic vessels, with the conglobate glands, and then to the circulation of blood - the hot topic of anatomy, still debated at the time. ${ }^{103}$ Starting in 1662, Steno began to look at muscle physiology more closely and, in a leap of anatomical mastery, he connected it again to the heart, by arguing that the heart itself was a muscle. ${ }^{104}$ As Steno delved more deeply into this new research, his mathematical yearnings continued to grow. Indeed, for Steno, mathematical arguments and concepts represented something deeper than they did for other anatomists. Later that year, in August 1662, Steno wrote a letter to Thomas Bartholin saying that, after he published the Observationes, he "had decided to lay down the anatomical knife until more convenient times and to take up again the nearly-cast-away geometer's rod."105 Such

\footnotetext{
${ }^{99}$ Roger French, William Harvey's Natural Philosophy (Cambridge: Cambridge University Press, 1994), p. 90.

${ }^{100}$ French, William Harvey's Natural Philosophy, p. 92.

${ }^{101}$ Bylebyl, "Nutrition, Quantification and Circulation," p. 383.

${ }^{102}$ Steno, Observationes, pp. 92-97 (BOP, pp. 490-4).

${ }^{103}$ In 1666, the physician Michele Lipari in Messina still argued that the pulse did not depend on the circulation of the blood but on vital spirits, see Bertoloni Meli, Mechanism, Experiment and Disease, pp. 58, 66. In 1670s France, physicians still gave long lectures against the circulation of the blood, see Guerrini, The Courtiers' Anatomists, pp. 207-9. See also Bartholin, Epistolarum medicinalium centuria III (Copenhagen, 1667), pp. 308-311: "De sanguinis circulatione dissensus"

${ }^{104}$ Steno, De musculis et glandulis observationum specimen, p. 22: "Cor vere musculum esse." (BOP, p. 562).

${ }^{105}$ Steno to Bartholin, 26 August 1662, in Bartholin, Epistolarum Medic-
}

a decision, however, did not move forward. In his own words,

hardly were my fingers, rid of blood, slightly besprinkled with this very pleasant powder [of geometry] that partly the fairly acid faces of famous gentlemen, partly their unfriendly writings that presented my opinion in a sense different from mine, denied me the happiness desired for a long time so that they imposed on me the necessity to answer and also to return to this bloody task. ${ }^{106}$

These strong words, although unrelated to the rest of the letter, were enough to show where Steno's heart was with respect to mathematics after his successful research on the glands. More importantly, it revealed a previous commitment of Steno's to mathematics for which, he said, "I spent many hours in the past and which I would have treated not as my primary, but as my unique work, if straitened circumstances at home had not so much convinced as forced me to prefer the useful to the pleasant." ${ }^{\prime 107}$ It is not yet clear what exactly Steno did in the many hours that he worked as a geometer in the past, but his studies in Copenhagen with Jorgen Eleirsen, the headmaster of his Latin school to whom Steno dedicated the treatise on the eye glands, might be the answer.

In May 1663, while travelling through Belgium with Ole Borch (1626-1690) and other friends, Steno met the mathematician Grégoire de Saint-Vincent (15841667) when visiting the Jesuit College of Ghent. ${ }^{108}$ De Saint-Vincent was an 80-year old Jesuit who became famous for his works on the quadrature of the circle and on mechanics, which might have attracted Steno's interests. ${ }^{109}$ By then, Steno was already working on his new

inalium Centuria IV (Copenhagen, 1667), p. 103: "Cum pauculas meas luci publicæ exponerem observationes, decreveram, repositio in commodiora tempora cultro Anatomico, Geometricum radium tantum non abjectum resumere." (BOP, p. 511).

${ }^{106}$ Steno to Bartholin, 26 August 1662, in Bartholin, Epistolarum IV, p. 103: "Sed vix purgati sangvine digiti jucundissimo illo pulvere leviter erant perspersi, cum Virorum Clarissimorum partim minæ satis acerbæ, partis scripta parum amica meamque sententiam sensu non meo proponentia desideratam diu felicitatem mihi inviderent, et ut respondendi, sic quoque ad sanguinarium illud excercitium revertendi imponerent necessitatem." (BOP, p. 511).

${ }^{107}$ Steno to Bartholin, 26 August 1662, in Bartholin, Epistolarum IV, p. 103: "non paucas olim impendi horas, quodque non ut primarium, sed ut unicum tractassem, nisi angusta domi res utilia jucundis præferenda non tam suasisset, quam imperasset."

${ }^{108}$ See H.D. Schepelern (ed.), Olai Borrichii Itinerarium 1660-1665 : the journal of the Danish polyhistor Ole Borch, 4 vols. (Copenhagen: Danish Society of Language and Literature, 1983), vol. 2, 26 May 1663: "Colloquium institutum in collegio Patris Societatis Jesus, cum patre à S. Vincentio jam octogenario, sed vivid adhuc, et novum scriptum intra biennium promittente."

${ }^{109}$ Geert Vanpaemel, "Jesuit Science in the Spanish Netherlands" in Moderchai Feingold (ed.), Jesuit Science and the Republic of Letters (Cambridge, MA, 2003), 389-432, esp. 391-397, 405-406, 418-420. 
book, De musculis et glandulis observationum specimen (1664). ${ }^{110}$ The book, published in 1664 in Copenhagen and Amsterdam, was his first printed work on muscle anatomy. ${ }^{11}$

In De musculis et glandulis, Steno relied again on mechanical analogies. For instance, when explaining how the muscles contract, Steno said that "it is not the tendon which contracts but the flesh comprised between the tendinous expansions." 112 To explain it better and, "since an explanation through similar things greatly pleases many people," Steno mentioned a complex pulley that brings structural posts to the ground by men holding ropes. ${ }^{113}$ In this example, the men control the machine by each one holding a single cable and pulling it together. In the muscles, the ropes represent the tendons, the weight hooked to the ropes represent the mobile part and the men themselves represent the fleshy fibers. By pulling their ropes together, said Steno, "the men indeed move the weight. Similarly, the contracting fleshy fibers, while they pull the fibers of the tendon move the mobile part." ${ }^{114}$ However, Steno did not push this analogy too far, and stated that it was "only a comparison." 115 Steno used a similar mechanical analogy when explaining the motion of the diaphragm, as he compared the abdomen to a pulley. ${ }^{116}$

If the use of mechanical analogies was similar to Steno's previous description of blood filtration on the glands, his geometrical descriptions, however, were much more explicit and served a more intentional purpose in this treatise than in previous ones. In the first part of the treatise, Steno said that most anatomists did not agree on the description of intercostal muscles, because such muscles are difficult to distinguish, although performing the same function together. How-

\footnotetext{
${ }^{110}$ Steno's first results on the muscles were reported in a letter to Thomas Bartholin from April 30, 1663. His first dissections on the muscles are mentioned in a letter to Bartholin from 26 August 1662. See Bertoloni Meli, "The Collaboration between Anatomists and Mathematicians," pp. 696-697.

111 The book was only printed in or after June, since it includes one letter sent on the 12 June 1664, in Nicolaus Steno, De musculis et glandulis (Copenhagen, 1664), p. 84.

112 Steno, De musculis et glandulis, p. 19: "Qui contrahitur, non tendo est, sed tendinosas inter expansiones comprehensa caro" (BOP, p. 561).

${ }^{113}$ Steno, De musculis et glandulis, p. 19: "cum per similia explicatio multis magnopere arrideat" (BOP, p. 561).

${ }^{114}$ Steno, De musculis et glandulis, p. 20: "ut enim homines breviores redditi, suas dum simul trahunt chordas, pondus movent; sic carneæ contractæ fibræ, dum tendinis trahunt fibras, mobilem movent partem." (BOP, p. 561).

${ }^{115}$ Steno, De musculis et glandulis, p. 20: "Sed cum simile hoc tantum sit, non diutius ipsi immorandum." (BOP, p. 561).

${ }^{116}$ Steno, De musculis et glandulis, p. 9: "Nec enim, cum vel maxime tenditur, in rectam extensum est, nec, circa qvam moveatur, trochleam habet (nisi abdominis hic volueris nominanda contenta)" (BOP, p. 555).
}

ever, Steno proposed to distinguish them according to "the different angles [they make] with the ribs." 117 Steno suggested that this categorization of the muscles carried an epistemological certainty almost as strong as mathematical certainty, for "the one who will not refuse to examine carefully the angles formed by the back, the ribs, the sternum and the muscles must find a demonstration of these muscles, perhaps not less certain than by mathematics." 118 Further on, after saying that every muscle was composed of fibers and tendons, Steno concluded that the fibers have a very specific disposition, as they "form an oblique parallelogram or the figure of a rhomboid" (fig. 4). ${ }^{119}$ After explaining how exactly the fibers and tendons were disposed in this geometrical figure, Steno felt the need to say that "even when dealing with physics, I give mathematical names to physical and not mathematical lines." 120 Steno was alluding to the old epistemological problem of mixed mathematics of whether natural things can be described by means of mathematical entities that do not exist perfectly in nature. Steno, however, felt it was better to "leave these details to mathematicians," and reinforced that both fibers and tendons are composed of fleshy fibers in a different concentration. ${ }^{121}$ Thus, Steno's commitment to mathematics was useful to him only in so far as it served the purpose of argumentation in anatomy. Another example comes from a "letter on the anatomy of a ray" to William Piso (1611-1678), included in De musculis et glandulis. ${ }^{122}$ Piso was an Amsterdam physician famous for his collaboration with the mathematician Georg MacGravius (1610-1644), with whom he wrote a widely-read natural history of Brazil. ${ }^{123}$ In this letter, Steno records not only the weights of the parts of the ray, but also comments on the animal's geometric shape, just like he had done with the muscles he was studying. ${ }^{124}$

\footnotetext{
${ }^{117}$ Steno, De musculis et glandulis, p. 6: "angulos cum costis constituunt diversos" (BOP, p. 553).

${ }^{118}$ Steno, De musculis et glandulis, pp. 9-10: "Sed his missis quorundam musculorum describam in respiratione usum, quorum demonstrationem Mathematica forte non minus certam non poterit non invenire, qui, quos dorsum, costæ, sternum, musculi inter se conficiunt, angulos attente examinare non recusaverit." (BOP, p. 555).

${ }^{119}$ Steno, De musculis et glandulis, p. 15: "Ejusdem ordinis fibræ in eodem plano sunt, et parallelogrammum obliquangulum, seu rhomboideam exhibent figuram." (BOP, p. 559).

${ }^{120}$ Steno, De musculis et glandulis, pp. 15-16: "Rem Physicam proponenti venia detur, si Mathematicis nominibus Physicas, non Mathematicas, designem lineas." (BOP, p. 559).

${ }^{121}$ Steno, De musculis et glandulis, p. 16: "Sed illam Mathematicis relinq-

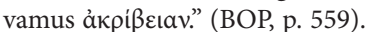

${ }^{122}$ Steno, De musculis et glandulis, p. 48: "De anatome rajæ epistola."

${ }^{123}$ In Leiden, Borch met MacGravius' brother, who mentioned a new book by Georg on "his mathematical speculations," apparently also edited by Piso. See Olai Borrichii Itinerarium, vol. 1, 27 April 1661, p. 115. ${ }^{124}$ Steno, De musculis, p. 15, 42 (BOP, p. 559, 580).
} 


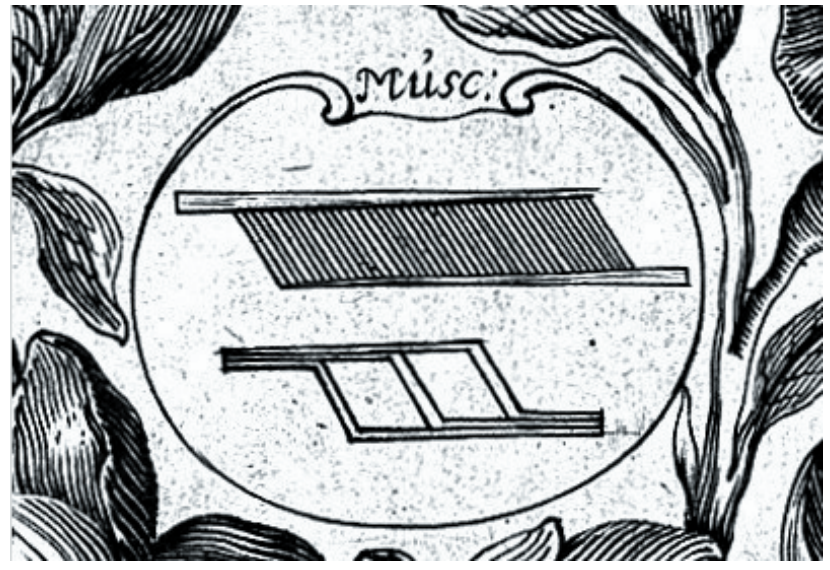

Figure 4. Geometrical representation of the muscles in the cover of Steno, De musculis et glandulis (Copenhagen, 1664). Courtesy of Wellcome Collection.

But Steno did not add a reason as to why he made these mathematical interventions. It was as if these approaches had already become regular and normal for him.

\section{MATHEMATICS AND NICOLAUS STENO'S ARRIVAL IN ITALY}

Considering that Steno had already explored mathematical methods for some time, it is fair to ask what he might have been looking for when he went to Italy for the first time, in the spring of 1666 . Before his arrival in Italy, Steno did not publish any other book. His famous dissection of the brain in 1665 in Paris only appeared in print four years later. And there are not many other writings from Steno's sojourn in France, although several scholars like Jan Swammerdam (1637-1680) and André Graindorge (1616-1676), wrote about their joint activities in Paris. ${ }^{125}$ However, the possibility that Steno interacted with French mathematicians like Gilles Personne de Roberval and Adrien Auzout, both of whom had collaborated with the anatomist Jean Pecquet, should not be disregarded. Steno's friendship with Melchisedec Thévenot (1620-1692), whose circles brought together some of the founding members of the Académie des Sciences de France, suggests that Steno might have shared his geometrical interests with them in the critical years before the publication of his seminal Elementorum myologice specimen. ${ }^{26}$ Steno expanded his mathematical

\footnotetext{
${ }^{125}$ Scherz's biography, in BOP, pp. 131-161

126 The Académie was founded within a year of Steno's sojourn. See Guerrini, The Courtiers' Anatomists, pp. 85-88; Nicholas Dew, Orientalism in Louis XIV's France (Oxford: Oxford University Press, 2009), pp. 89-92.
}

approach in that book, a full treatise on the mathematical elements of myology, where he explained better the rhomboid structure of muscles.

The book also "call[ed] upon the testimony of Vincenzo Viviani, mathematician of the most serene Grand Duke, who was present as a keen observer of these facts and of others contained in the present book." 127 It could be that Steno went to Italy in search of the mathematical and experimental legacy of Galileo, Viviani and Borelli. But Steno never mentioned them in his anatomical works, even when writing on mathematics. And Steno's mention of Galileo in his student notebook from 1659 in Copenhagen is very short, compared to his notes on the writings of Athanasius Kircher, Jean Pecquet and Pierre Gassendi. ${ }^{128}$ This is not to say that Steno was not influenced by the school of Galileo later on in Florence. Troels Kardel rightly points out the striking differences between the De musculis et glandulis (Copenhagen, 1664) and the Elementorum myologice specimen (Florence, 1667), especially the role of images. And Domenico Bertoloni Meli argues that the latter's life-size images carried demonstrative power for Steno in the same way as accounts of experiments carried for Galileo. ${ }^{129}$ Bertoloni Meli also points out that Steno's use of the terms inaequaliter aequaliter to describe the disposition of fibers between tendons, resembles the famous Galileo description of the uniformly accelerated motion. ${ }^{130}$ Thus, whereas the school of Galileo played an important role in shaping Steno's later writings, it does not seem to have been at the heart of the matter earlier on. In fact, to understand the factors that led Steno and other anatomists to mathematics, it is perhaps useful to look away from the shadow of Galileo, Descartes and other great names of seventeenth-century science. ${ }^{131}$

Finally, even though Steno did not mention it, he was likely aware of the Italian school of mathematics. The intellectual circles he frequented in the Netherlands and France were well informed of the scientific developments of Italy, often due to a competitive spirit. An example to be explored further is the race for the lost manuscripts of Apollonius' conics, led by Steno's professor of mathematics Jacob Golius in Leiden and by Borelli in Florence

\footnotetext{
127 Steno, Elementorum myologioe specimen, p. 119: "amicissimum mihi Vincentium Viviani, Serenissimi Magni Ducis Mathematicum, testem appello" (BOP, 739).

${ }^{128}$ Ziggelaar, Chaos, pp. 301-2.

${ }^{129}$ Bertoloni Meli, "The Collaboration between Anatomists and Mathematicians," pp. 705-706.

${ }^{130}$ Bertoloni Meli, "The Collaboration between Anatomists and Mathematicians," p. 706.

${ }^{131}$ Steno's mentors were generally critics of Cartesian anatomy. For Bartholin on Descartes see Jesper Andersen, Thomas Bartholin: Logen \& anatomen (Copenhagen: FADL's Forlag, 2017), pp. 52-62; for Sylvius and Van Horne see Ragland, "Mechanism, the Senses, and Reason."
} 
around 1660. ${ }^{132}$ When Steno visited Borelli in his first months in Florence, the latter was already working on his De motu animalium, published posthumously. ${ }^{133}$ Yet, the absence of all these references in Steno's writings only makes him a more interesting character, and speaks to the larger role of mathematics and its broader influences in Steno's career before arriving in Italy.

\section{CONCLUSION}

If anything, this article shows that Steno's interest in mathematics had been in his mind at least since his interaction with Jorgen Eilersen as a young student in Denmark. In Leiden, Steno's first publications on the glands made use of mathematical ideas, not just with mechanical analogies, but also with the measuring of weights of the parotid glands and the uses of the concepts of lubrication, speed flow to explain the production of salivary and lachrymal fluids. Later on, in De musculis et glandulis, Steno continued to rely on mechanical analogies while at the same time moving to a deeper use of geometry, by describing the muscles with the geometrical figure of a rhomboid. Steno's attraction to mathematics in his early anatomical research thus becomes an important case of how an anatomist transferred arguments and methods from geometry and mechanics into anatomy and the life sciences, and sheds light on the growing influence of the mixed mathematics and physics in the history of science up to modern times.

\footnotetext{
${ }^{132}$ Luigi Guerrini, "Matematica ed Erudizione. Giovani Alfonso Borelli e l'Edizione Fiorentina dei Libri V, VI e VII delle Coniche di Apollonio di Perga" Nuncius 14 (1999), pp. 505-568.

${ }^{133}$ In a letter to Marcello Malpighi from 1667, Giovanni Battista Capucci mentions Borelli's work and its similarity to Steno's Elementorum myologioe specimen, see Capucci to Malpighi, 25 July 1667, in Adelmann, The Correspondence of Marcello Malpighi, vol. 1, p. 352: "[Borelli] ha promesso a' nostri amici di colà in breve tempo il suo libro de motu animalium, del qual argomento, Dio voglia, ch'il Sr. Stenone non se n'abbia tolto il meglio, così come ha prevenuto in publicarlo, mentre questo come Vostra Signoria Eccellentissima dice anche procede con principij geometrici. Non bisogna publicar l'idee di belle cose, e tirarne a lungo la composizione, e la stampa, sé non vogliono esser involate."
} 